De Jure: Jurnal Hukum dan Syari'ah

Vol. 9, No. 2, 2017, h. 63-72

ISSN (Print): 2085-1618, ISSN (Online): 2528-1658

DOI: http://dx.doi.org/10.18860/j-fsh.v9i2.6807

Available online at http://ejournal.uin-malang.ac.id/index.php/syariah

\title{
Iktikat Baik Para Pihak dalam Pelaksanaan Mediasi di Pengadilan Agama
}

\author{
Amiril Lizuardi \\ Kementerian Luar Negeri RI \\ amirillazuardi@gmail.com
}

\author{
Sudirman \\ UIN Maulana Malik Ibrahim Malang \\ sudirmansyariah@as.uin-malang.ac.id
}

\author{
Ahmad Izzuddin \\ UIN Maulana Malik Ibrahim Malang \\ azharzudin@syariah.uin-malang.ac.id
}

\begin{abstract}
Abstrak:
This article aims to describe the principle of good faith in the Supreme Court Regulation No. 1 of 2016 concerning Mediation in the Court while at the same time describing the implementation of the principle of good faith in the conduct of mediation in the Malang District Religious Court. This research is included in empirical research using a qualitative approach. The results of the discussion of this article indicate that Mediation is an inseparable part of the procedure in the Religious Courts as stipulated in the Indonesian Supreme Court Regulation Number 1 of 2016 concerning Procedure for Mediation in Courts. In the Republic of Indonesia's Supreme Court Regulation Number, 1 of 2016, the provisions of good faith in the implementation of mediation were added. The mediator has the authority to evaluate the intentions of the parties during the mediation.

Artikel ini bertujuan mendeskripsikan asas iktikad baik dalam Peraturan Mahkamah Agung RI Nomor 1 Tahun 2016 tentang Mediasi di Pengadilan sekaligus mendeskripsikan implementasi asas iktikad baik dalam pelaksanaan mediasi di Pengadilan Agama Kabupaten Malang. Penelitian ini termasuk dalam penelitan empiris dengan menggunakan pendekatan kualitatif. Hasil pembahasan artikel ini menunjukkan bahwa Mediasi merupakan bagian yang tidak dapat dipisahkan dari prosedur beracara di Pengadilan Agama sebagaimana diatur dalam Peraturan Mahkamah Agung RI Nomor 1 Tahun 2016 tentang Prosedur Mediasi di Pengadilan. Dalam Peraturan Mahkamah Agung RI Nomor 1 Tahun 2016 ditambahkan tentang ketentuan iktikad baik dalam pelaksanaan mediasi. Mediator memiliki wewenang untuk melakukan penilaian terhadap iktikad para pihak selama pelaksanaan mediasi.
\end{abstract}

Kata Kunci: mediasi; pengadilan agama; iktikad baik. 


\section{Pendahuluan}

Konflik dan harmoni merupakan dua hal yang selalu ada dalam masyarakat. Konflik yang dikelola dengan baik dapat menghasilkan toleransi dan harmoni. Sebalinya, konflik yang tidak terkendali akan mengakibatkan permusuhan dan kerusakan. ${ }^{1}$ Konflik terjadi karena beberapa sebab, seperti keterbatasan sumberdaya, komunikasi yang tidak baik, kesenjangan sosial, kekerasan, ketidakadilan, perbedaan identitas, dan benturan antar budaya. Ada banyak cara menyelesaikan konflik, salah satunya menggunakan jalur mediasi. ${ }^{2}$ Secara umum, mediasi merupakan perundingan antara para pihak yang bersengketa dengan melibatkan pihak ketiga yang bersifat netral dan tidak berpihak. ${ }^{3}$ Mediasi dapat digunakan untuk menyelesaikan sengketa diberbagai bidang kehidupan, seperti perkawinan, kewarisan, medis, agraria, bisnis, agama, politik dan suku. Mediasi juga mulai digunakan untuk menyelesaikan tindak pidana. ${ }^{4}$

Mediasi memiliki berbagai keuntungan, antara lain: (a) prosedur dan waktu yang fleksibel; (b) hasil mediasi bersifat win-win solution; (c) rahasia para pihak terjamin; dan (d) menjaga hubungan para pihak di kemudian hari. ${ }^{5}$ Berbagai kelebihan ini menjadi dasar bagi Mahkamah Agung RI untuk mengintegrasikan mediasi ke dalam sistem peradilan. Pada tahun 2002, Mahkamah Agung mengeluarkan SEMA Nomor 1 Tahun 2002 tentang Pemberdayaan Pengadilan Tingkat Pertama Menerapkan Lembaga Damai. Kemudian pada tahun 2003, Mahkamah Agung mengeluarkan PERMA Nomor 2 Tahun 2003 tentang Prosedur Mediasi di Pengadilan. Pengintegrasian ini bertujuan mengurangi penumpukan perkara di pengadilan, menerapkan asas cepat, sederhana, dan biaya ringan, serta memberikan akses keadilan seluas-luasnya terhadap para pihak yang berperkara. ${ }^{6}$

Pada tahun 2008, ketentuan pelaksanaan mediasi di pengadilan diubah melalui PERMA Nomor 1 Tahun 2008. Peraturan baru ini bertujuan meningkatkan akses keadilan dan mengimplementasikan asas cepat, sederhana, dan biaya ringan. ${ }^{7}$ Selain itu, peraturan ini diharapkan mampu memberikan kepastian, ketertiban, kelancaran pelaksanaan mediasi di pengadilan. ${ }^{8}$ Para pihak yang bersengketa didorong untuk bersama-sama menyelesaikan persoalan mereka, dengan perantara pihak ketiga. Melalui peraturan ini, mediasi diakui sebagai bagian integral dari proses beracara di pengadilan. Setiap penyelesaian perkara perdata wajib dilakukan mediasi terlebih dahulu. Termasuk di antaranya adalah perkara perkawinan, kewarisan, hibah, wasiat dan ekonomi syariah. Majelis hakim hanya dapat melanjutkan pemeriksaan pokok perkara jika mediasi

\footnotetext{
${ }^{1}$ Erik Sabti Rahmawati, "Implikasi Mediasi Bagi Para Pihak yang Berperkara di Pengadilan Agama Malang," De Jure: Jurnal Hukum dan Syariah 8, no. 1 (June 25, 2016): 2, https://doi.org/10.18860/jfsh.v8i1.3725.

2 Siradjuddin Siradjuddin, "Akar-Akar Konflik Fundamental Perspektif Ekonomi Politik," Jurnal Iqtisaduna 1, no. 2 (December 19, 2015): 25, https://doi.org/10.24252/iqtisaduna.v1i2.1192.

${ }^{3}$ Bambang Sutiyoso, Hukum Arbitrase Dan Alternatif Penyelesaian Sengketa (Yogyakarta: Gama Media, 2008), 58.

${ }^{4}$ Agus Raharjo, "Mediasi Sebagai Basis Dalam Penyelesaian Perkara Pidana," Mimbar Hukum - Fakultas Hukum Universitas Gadjah Mada 20, no. 1 (2008): 105, https://doi.org/10.22146/jmh.16316.

5 Ahwan Fanani, Pengantar Mediasi (Fasilitatif), Prinsip, Metode, Dan Teknik (Semarang: Fakultas Tarbiyah IAIN Walisongo Semarang, 2012), 13.

${ }^{6}$ Rahardi Wasi Bintoro and Tedi Sudrajat, "Analisis Mengenai Materi Muatan Peraturan Mahkamah Agung Nomor 2 Tahun 2003 Tentang Prosedur Mediasi Pengadilan,” Jurnal Dinamika Hukum 8, no. 1 (January 15, 2008): 2, https://doi.org/10.20884/1.jdh.2008.8.1.16.

${ }^{7}$ Prianter Jaya Hairi, “Antara Prinsip Sederhana, Cepat, Dan Berbiaya Ringan Dan Gagasan Pembatasan Perkara Kasasi," Negara Hukum 2, no. 1 (June 2011): 152.

8 Abdul Halim Talli, "Mediasi dalam PERMA Nomor 1 Tahun 2008," Jurnal Al-Qadau: Peradilan dan Hukum Keluarga Islam 2, no. 1 (June 8, 2015): 86.
} 
dinyatakan gagal. ${ }^{9}$ Bagi majelis hakim yang enggan menerapkan prosedur mediasi, maka putusan yang dihasilkan batal demi hukum. ${ }^{10}$

Pelaksanaan mediasi di pengadilan belum sesuai dengan harapan. Masyarakat belum menggunakan mediasi sebagai sarana penyelesaian sengketa secara optimal. Sebagian besar mediasi di pengadilan dinyatakan tidak berhasil. Salah satu faktornya ada pada para pihak sendiri. Para pihak tidak memiliki iktikad baik untuk menempuh proses mediasi. Hal ini dibuktikan dengan ketidakhadiran para pihak dalam mediasi setelah dilakukan pemanggilan secara patut. ${ }^{11}$ Keengganan para pihak untuk hadir dalam proses mediasi, disinyalir karena para pihak ingin mempercepat penyelesaian perkara mereka di pengadilan. Mediasi pada akhirnya hanya formalitas hukum acara belaka. Kondisi ini diperburuk dengan keinginan kuat serta ego para pihak untuk memenangkan sengketa yang sedang terjadi. ${ }^{12}$ Pada tahun 2016, Mahkamah Agung RI merevisi aturan tentang mediasi di pengadilan. PERMA Nomor 1 Tahun 2008 diganti dengan PERMA Nomor 1 Tahun 2016. Sisi menarik dalam peraturan ini adalah adanya kewajiban melaksanakan iktikad baik dalam proses mediasi, baik para pihak yang bersengketa maupun kuasa hukumnya. ${ }^{13}$

Berlakunya PERMA Nomor 1 Tahun 2016 membawa dampak positif terhadap pelaksanaan mediasi di Pengadilan Agama Kabupaten Malang. Jumlah perkara yang dapat dimediasi berangsur mengalami peningkatan. Artikel ini berargumen bahwa mediasi yang menjadi bagian dari hukum acara yang diterapkan di Pengadilan Agama Kabupaten Malang, wajib ditempuh oleh para pihak yang berperkara. Kesuksesan mediasi di Pengadilan Agama Kabupaten Malang berkaitan dengan iktikad baik dan kesukarelaan para pihak. Berdasarkan persoalan diatas, artikel ini bertujuan mendeskripsikan asas iktikad baik dalam Peraturan Mahkamah Agung RI Nomor 1 Tahun 2016 tentang Mediasi di Pengadilan sekaligus mendeskripsikan implementasi asas iktikad baik dalam pelaksanaan mediasi di Pengadilan Agama Kabupaten Malang.

\section{Metode Penelitian}

Penelitian ini termasuk dalam penelitan empiris dengan menggunakan pendekatan kualitatif. Penelitian ini dilaksanakan di Pengadilan Agama Kabupaten Malang. Pemilihan lokasi didasarkan pada banyaknya jumlah perkara yang diajukan di pengadilan agama ini. Data primer penelitian diperoleh dengan cara wawancara mendalam dengan mediator yang bertugas di Pengadilan Agama Kabupaten Malang. Adapun sumber data sekunder diperoleh dari buku, artikel jurnal, data statistik, laporan, dan peraturan perundang-undangan yang berkaitan dengan pelaksanaan mediasi dipengadilan. Pengecekan keabsahan data dilakukan dengan menggunakan metode triangulasi sumber, yaitu membandingkan sumber data primer dan sumber data sekunder.

\footnotetext{
${ }^{9}$ Bintoro and Sudrajat, “Analisis Mengenai Materi Muatan Peraturan Mahkamah Agung Nomor 2 Tahun 2003 Tentang Prosedur Mediasi Pengadilan," 17.

${ }^{10}$ Siti Musawwamah, "Mediasi Integratif Di Pengadilan Agama Pamekasan," NUANSA: Jurnal Penelitian Ilmu Sosial Dan Keagamaan Islam 11, no. 2 (January 18, 2014): 350, https://doi.org/10.19105/nuansa.v11i2.537.

${ }^{11}$ Supardi Supardi and Zahrotul Hanifiyah, "Penyebab Kegagalan Mediasi Dalam Proses Perceraian (Studi Kasus Di Pengadilan Agama Kudus Periode Januari-April 2017)," YUDISIA : Jurnal Pemikiran Hukum Dan Hukum Islam 8, no. 1 (April 8, 2018): 172-73, https://doi.org/10.21043/yudisia.v8i1.3224.

12 Rina Antasari, "Pelaksanaan Mediasi dalam Sistem Peradilan Agama (Kajian Implementasi Mediasi dalam Penyelesaian Perkara di Pengadilan Agama Kelas I A Palembang)," Intizar 19, no. 1 (2013): 157.

13 Dian Mustika, "Efektivitas Mediasi Dalam Penyelesaian Perkara Perceraian Di Pengadilan Agama Jambi," AL-RISALAH 15, no. 2 (December 20, 2015): 302.
} 


\section{Hasil dan Pembahasan \\ Iktikad Baik dalam Proses Mediasi di Pengadilan Agama}

Salah satu ketentuan baru yang dimuat dalam Peraturan Mahkamah Agung RI Nomor 1 Tahun 2016 yaitu iktikad baik dalam pelaksanaan mediasi di pengadilan. Iktikad baik (good faith) lazim dikenal dalam pelaksanaan kontrak. Pasal 1338 ayat (3) KUHPerdata menyatakan bahwa perjanjian harus dilaksanakan dengan iktikad baik. Secara teoritis iktikad baik dibagi menjadi dua: 1) iktikad baik subjektif. Para pihak sebelum perjanjian disepakati harus bersikap jujur dan terbuka. Tidak ada agenda tersembunyi dibalik proses negosiasi yang sedang berlangsung; 2) iktikad baik objektif yaitu pelaksanaan perjanjian harus sesuai dengan kepatutan dan keadilan. ${ }^{14}$ KUHPerdata tidak memberikan penjelasan lebih lanjut tentang iktikad baik. Jika terjadi perselisihan, hakim diberikan wewenang untuk memberikan tafsiran apakah perjanjian yang dilaksanakan bertentangan iktikad baik, yaitu kepatutan dan keadilan. ${ }^{15}$

Asas iktikad baik dalam pelaksanaan mediasi diatur dalam Pasal 7 PERMA Nomor 1 Tahun 2016. Para pihak dan/atau kuasa hukumnya wajib melaksanakan mediasi dengan iktikad baik. Mediator dapat memberikan penilaian terhadap iktikad baik para pihak dan/atau kuasa hukumnya dengan ketentuan sebagai berikut: 1) tidak hadir setelah dilakukan pemanggilan secara catut 2 kali berturut-turut tanpa ada alasan yang sah seperti: a) sakit yang dibuktikan dengan surat keterangan dokter; b) berada di bawah pengampuan; c) memiliki tempat tinggal atau domisili di luar negeri; d) menjalankan tugas negara atau tuntutan profesi yang tidak bisa ditinggalkan. Meskipun demikian, Pasal 6 ayat (2) memperbolehkan para pihak melakukan mediasi melalui komunikasi audio visual jarak jauh; 2) para pihak menghadiri pertemuan pertama tetapi tidak hadir pada pertemuan selanjutnya setelah dilakukan pemanggilan sebanyak 2 kali berturut-turut tanpa alasan yang sah; 3) ketidakhadiran para pihak secara berulang dalam mediasi yang mengganggu jadwal mediasi tanpa adanya alasan yang sah; d) menghadiri mediasi tetapi tidak memberikan respons terhadap resume perkara pihak lain; e) tidak menandatangani hasil mediasi yang telah disepakati tanpa alasan yang sah. PERMA Nomor 1 Tahun 2016 juga memberikan ketentuan tentang konsekuensi yang harus dihadapi para pihak yang tidak memiliki iktikad baik dalam mediasi. Pasal 22 memberikan ketentuan bahwa penggugat yang dinyatakan tidak beriktikad baik oleh mediator, maka gugatannya tidak dapat diterima oleh hakim pemeriksa perkara dan diwajibkan membayar biaya mediasi. Setelah mendapatkan laporan dari mediator, majelis hakim pemeriksa perkara memberikan putusan akhir yang menyatakan gugatan tidak dapat diterima disertai penghukuman membayar biaya mediasi dan biaya perkara. Biaya mediasi dapat diambilkan dari panjar atau biaya tersendiri untuk diserahkan kepada tergugat melalui kepaniteraan pengadilan. ${ }^{16}$

Gugatan tidak dapat diterima juga dikenal dengan sebutan net ontvankelijke verklaard (NO). Gugatan tidak memenuhi ketentuan formil sebagaimana diatur dalam ketentuan hukum acara perdata, seperti gugatan tidak disertai fundamentum petendi, obscur libel, eror in persona, nebis in idem, tidak ada petitum, gugatan prematur, atau gugatan telah daluwarsa. Gugatan tidak dapat diterima juga dapat disebabkan adanya

\footnotetext{
14 Antari Innaka, Saida Rusdiana, and Sularto, "Penerapan Asas Iktikad Baik Terhadap Pra Kontraktual Pada Perjanjian Jual Beli Perumahan,” Mimbar Hukum 24, no. 3 (2012): 505.

${ }^{15}$ Marwah, “Asas Iktikad Baik Dalam Perjanjian Kredit Pemilikan Rumah,” Jurisprudentie 3, no. 1 (2016): 89.

${ }^{16}$ Peraturan Mahkamah Agung RI Nomor 1 Tahun 2016 tentang Mediasi di Pengadilan dimuat dalam Berita Negara Tahun 2016 Nomor 175
} 
eksepsi atau tangkisan baik terhadap kompetensi absolut maupun relatif pengadilan. ${ }^{17}$ Jika para pihak yang berkepentingan merasa tidak puas dengan putusan ini, mereka memiliki hak mengajukan kembali gugatannya ke pengadilan yang sama sebagai perkara yang baru. Menurut Yahya Harahap, cara yang paling efektif dan efisien untuk mengajukan kembali gugatan yang tidak dapat diterima yaitu dengan memperbaiki cacat formil yang ada dalam gugatan sebelumnya, bukan dengan mengajukan banding maupun kasasi. Karena boleh jadi pengadilan yang lebih tinggi membenarkan putusan dari pengadilan tingkat pertama. ${ }^{18}$ Berdasarkan hal ini, jika gugatan tidak dapat diterima karena pihak penggugat dinyatakan tidak beriktikad baik dalam proses mediasi, maka ia cukup memperbaiki kesalahannya dalam proses mediasi, sebelum mengajukan kembali gugatannya di pengadilan.

Sedangkan untuk tergugat yang tidak memiliki iktikad baik dikenai kewajiban membayar biaya mediasi. Mediator wajib menyampaikan laporan bahwa tergugat tidak memiliki iktikad baik kepada majelis hakim pemeriksa perkara disertai dengan rekomendasi biaya mediasi dan perhitungan besarannya. Majelis hakim kemudian mengeluarkan penetapan yang menyatakan pihak tergugat tidak memiliki iktikad baik dan menghukum tergugat membayar biaya mediasi. Biaya Mediasi merupakan bagian dari biaya perkara yang wajib disebutkan dalam amar putusan akhir. Tergugat dimenangkan dalam putusan, amar putusan menyatakan biaya mediasi dibebankan kepada tergugat, sedangkan biaya perkara tetap dibebankan kepada penggugat sebagai pihak yang kalah. Dalam perkara perceraian di lingkungan peradilan agama, tergugat sebagaimana dimaksud dihukum membayar biaya mediasi, sedangkan biaya perkara dibebankan kepada penggugat. Pembayaran biaya mediasi oleh tergugat yang akan diserahkan kepada penggugat melalui kepaniteraan pengadilan mengikuti pelaksanaan putusan yang telah berkekuatan hukum tetap. Jika mediator menyatakan bahwa para pihak secara bersama-sama tidak beriktikad baik dalam mediasi, gugatan dinyatakan tidak dapat diterima oleh hakim pemeriksa perkara tanpa penghukuman biaya mediasi. ${ }^{19}$ Ketentuan tentang iktikad baik dalam mediasi merupakan respons Mahkamah Agung terhadap realitas pelaksanaan mediasi di pengadilan. PERMA Nomor 1 Tahun 2016 ini merupakan jawaban atas berbagai kendala yang terjadi dalam pelaksanaan mediasi, khususnya yang berasal dari para pihak. PERMA ini berupaya memberikan efek jera kepada para pihak yang secara sengaja tidak memiliki iktikad baik dalam proses mediasi. Selain itu, Mahkamah Agung berupaya memberikan edukasi kepada masyarakat tentang urgensi lembaga perdamaian daripada menyelesaikan persoalannya melalui jalur litigasi, yang merupakan ultimum remidium.

\section{Pelaksanaan Mediasi di Pengadilan Agama Kabupaten Malang}

Pengadilan Agama Kabupaten Malang merupakan pengadilan tingkat pertama yang memiliki wewenang menerima, memeriksa, memutus, dan menyelesaikan perkara perkara ditingkat pertama antara orang-orang yang beragama Islam dibidang perkawinan, kewarisan, wasiat dan hibah yang dilakukan berdasarkan hukum Islam serta wakaf, zakat,

\footnotetext{
17 Rai Mantili and Samanta Aulia Lubis, "Pertimbangan Hakim Pengadilan Negeri Terhadap Gugatan Perceraian Yang Tidak Dapat Diterima (Niet Ontvankelijke Verklaard) Dalam Praktik,” ADHAPER: Jurnal Hukum Acara Perdata 3, no. 1 (2017): 125.

${ }^{18}$ Mantili and Lubis, 130-31.

${ }^{19}$ Peraturan Mahkamah Agung RI Nomor 1 Tahun 2016 tentang Mediasi di Pengadilan dimuat dalam Berita Negara Tahun 2016 Nomor 175
} 
infaq dan shadaqah serta ekonomi syariah. ${ }^{20}$ Pengadilan Agama Kabupaten Malang termasuk salah satu satuan kerja di lingkungan Mahkamah Agung yang banyak menerima perkara setiap tahunnya. Adapun gambaran umum perkara di Pengadilan Agama Kabupaten Malang Tahun 2016 sebagai berikut:

Tabel 1. Jumlah Perkara Gugatan di Pengadilan Agama Kabupaten Malang ${ }^{21}$

\begin{tabular}{llrrrr}
\hline No & Bulan & $\begin{array}{c}\text { Sisa Bulan } \\
\text { Lalu }\end{array}$ & Masuk & Putus & \multicolumn{1}{c}{ Sisa } \\
\hline 1 & Januari & 1438 & 785 & 682 & 1541 \\
\hline 2 & Februari & 1541 & 704 & 708 & 515 \\
\hline 3 & Maret & 1537 & 758 & 794 & 1501 \\
\hline 4 & April & 1501 & 695 & 665 & 1531 \\
\hline 5 & Mei & 1531 & 750 & 722 & 1559 \\
\hline 6 & Juni & 1559 & 451 & 775 & 1235 \\
\hline 7 & Juli & 1235 & 541 & 383 & 1393 \\
\hline 8 & Agustus & 1393 & 862 & 629 & 1626 \\
\hline 9 & September & 1626 & 740 & 810 & 1556 \\
\hline
\end{tabular}

Dari 6168 perkara yang diputus oleh Pengadilan Agama, hanya 493 perkara saja yang dapat dimediasi. ${ }^{22}$ Kecilnya angka perkara yang masuk ke proses mediasi disebabkan ketidakhadiran para pihak dalam proses mediasi. Selain itu, banyak perkara yang diputus secara verstek. Baik karena pihak tergugat tidak hadir setelah dilakukan pemanggilan secara patut, yaitu dua kali berturut-turut tanpa adanya alasan yang sah. ${ }^{23}$ Berdasarkan fenomena ini, ada indikasi kuat bahwa sejak awal perkara didaftarkan di kepaniteraan Pengadilan Agama Kabupaten Malang para pihak, khususnya tergugat tidak memiliki iktikad baik untuk mengikuti proses mediasi, baik karena alasan pragmatis sepeti mempercepat jalannya proses persidangan maupun tergugat tidak diketahui kedudukannya di seluruh wilayah Indonesia. Ketidakhadiran para pihak dalam proses mediasi mengindikasikan bahwa masyarakat memiliki budaya hukum yang masih rendah. Menurut Laurence M. Friedman, budaya hukum mengandung seperangkat nilai yang menjadi dasar perumusan kebijakan dan pembuatan hukum. Berbagai aturan yang telah dirumuskan diharapkan mencerminkan nilai-nilai luhur yang dimiliki oleh bangsa yang bersangkutan. ${ }^{24}$ Mediasi merupakan manifestasi dari nilai-nilai luhur bangsa Indonesia yang mengedepankan musyawarah mufakat dalam menyelesaikan problem bersama. Musyawarah mufakat memiliki beberapa ciri yaitu: 1) keputusan diambil untuk kepentingan bersama; 2) musyawarah yang dilakukan atas dasar perasaan kekeluargaan; 3) musyawarah dilakukan dengan iktikad baik dan rasa tanggung jawab menerima serta melaksanakan hasil keputusan; 4) musyawarah dilaksanakan berdasarkan hati nurani dan akal sehat; 5) keputusan yang diambil wajib dipertanggungjawabkan secara moral kepada

\footnotetext{
${ }^{20}$ Pasal 49 Undang-Undang Nomor 3 Tahun 2006 Jo. Undang-Undang Nomor 50 tahun 2009 tentang Peradilan Agama.

${ }^{21}$ Pengadilan Agama Kabupaten Malang, "Laporan Statistik Perkara Pengadilan Agama Kabupaten Malang 2016," October 2016, https://sipp.pa-malangkab.go.id/statistik_perkara.

22 Data Statitistik Mediasi Pengadilan Agama Kabupaten Malang Tahun 2016

${ }^{23}$ Solihin, Wawancara (Malang: 26 Oktober 2016)

${ }^{24}$ Iman Pasu Marganda Hadirto Purba, "Penguatan Budaya Hukum Masyarakat Untuk Menghasilkan Kewarganegaraan Transformatif,” Jurnal Civics 14, no. 2 (October 2017): 147.
} 
Tuhan Yang Maha Esa, menjunjung tinggi hak asasi manusia, nilai keberasan dan keadilan. $^{25}$

Kurangnya pengetahuan masyarakat terhadap manfaat mediasi menjadi faktor penghambat pelaksanaan mediasi. Faktor penghambat lainnya yaitu sikap pasif para pihak. Tidak jarang ditemui para pihak hanya menunggu pertanyaan dari mediator, menanggapi secara singkat, seringkali kurang jelas. Hal ini menyebabkan informasi yang diterima oleh mediator tentang perkara yang dihadapi tidak sepenuhnya jelas. Kondisi ini menyulitkan mediator untuk memandu jalannya mediasi guna menemukan solusi sehingga tercapai kesepakatan damai/ berhasil dalam mediasi. ${ }^{26}$ Menurut Purba, kondisi ini dapat diatasi melalui pendidikan dan sosialisasi peraturan perundang-undangan. Namun, agenda pembangunan kesadaran hukum akan lebih efektif jika dimulai dari keluarga sebagai unit terkecil dalam masyarakat. Melalui sosialisasi ini masyarakat diharapkan mengetahui hak, dan kewajiban mereka serta memahami berbagai resiko dari perbuatan hukum yang dilakukan. ${ }^{27}$

Pengadilan Agama Kabupaten Malang telah mengimplementasikan ketentuan PERMA Nomor 1 Tahun 2016 pada bulan Juni 2016. Karena pemberlakuan PERMA ini perlu adanya penyesuaian dan waktu untuk disosialisasikan kepada semua pihak, khususnya kepada para hakim dan mediator di lingkungan Pengadilan Agama Kabupaten Malang. ${ }^{28}$ PERMA Nomor 1 Tahun 2016 membawa dampak bagi pelaksanaan mediasi di Pengadilan Agama Kabupaten Malang. Mediasi tidak hanya diukur dengan berhasil atau tidaknya pihak penggugat mencabut perkaranya. Mahkamah Agung menambahkan satu bentuk keberhasilan mediasi, yaitu kesepakatan perdamaian sebagian. Pasal 29 ayat (1) menyatakan bahwa dalam hal proses mediasi mencapai kesepakatan antara penggugat dan sebagian pihak tergugat, penggugat mengubah gugatan dngan tidak lagi mengajukan pihak tergugat yang tidak mencapai kesepakatan sebagai pihak lawan. Kesepakatan ini sepanjang tidak menyangkut aset, harta, atau kepentingan dari pihak tergugat yang tidak sepakat untuk berdamai. Penggugat dapat mengajukan kembali gugatannya kepada pihak yang tidak bersepakat dalam proses mediasi. ${ }^{29}$

Tabel 2. Data Perkara Mediasi di Pengadilan Agama kabupaten Malang ${ }^{30}$

\begin{tabular}{lcccc}
\hline \multicolumn{1}{c}{ Bulan } & Berhasil & $\begin{array}{l}\text { Berhasil. } \\
\text { Sebagian }\end{array}$ & Gagal & Jumlah \\
\hline Januari & - & - & 66 & 66 \\
\hline Pebruari & - & - & 61 & 61 \\
\hline Maret & - & - & 61 & 61 \\
\hline April & - & - & 55 & 55 \\
\hline Mei & - & - & 75 & 75 \\
\hline Juni & 1 & 47 & 15 & 63 \\
\hline Juli & - & 21 & 11 & 32 \\
\hline Agustus & 3 & 68 & 9 & 80 \\
\hline
\end{tabular}

25 Suyahmo, "Model Implementasi Sila Ke 4 Kerakyatan Yang Dipimpin Oleh Hikmat Kebijaksanaan Dalam Permusyawaratan/Perwakilan Sebagai Lokus Pendidikan Demokrasi Di Smp Kota Semarang," Jurnal Penelitian Pendidikan 32, no. 1 (2015): 55.

${ }^{26}$ Musleh Herry, Wawancara (Malang: 18 Oktober 2016)

${ }^{27}$ Purba, "Penguatan Budaya Hukum Masyarakat," 150-51.

${ }^{28}$ Musleh Herry, Wawancara (Malang: 18 Oktober 2016)

${ }^{29}$ Pasal 29 Peraturan Mahkamah Agung Nomor 1 tahun 2016 tentang Prosedur Mediasi di Pengadilan

30 Tabel data Perkara mediasi di Pengadilan Agama kabupaten Malang, diolah tanggal 10 September 2016 
Kesuksesan pelaksanaan mediasi tidak hanya penyempurnaan peraturan melalui PERMA Nomor 1 Tahun 2016. Melainkan juga karena faktor pelayanan yang baik dan profesional dari setiap mediator yang bertugas di Pengadilan Agama Kabupaten Malang. Pelaksanaan mediasi di Pengadilan Agama Kabupaten Malang berupaya dengan sungguh-sungguh mengurangi perkara yang masuk, khususnya kasus perceraian. Dalam pelaksanaan mediasi, mediator juga memberikan waktu kepada para pihak untuk menyampaikan permasalahan yang dihadapi, menceritakan secara detail dan menyeluruh tentang gejala permasalahan yang dihadapi, untuk kemudian mediator menjadi tempat untuk menuangkan segala aspek dan sebab permasalahan tersebut terjadi. Dari cerita yang dipaparkan oleh para pihak saat itu pula mediator mencoba mencari titik temu dan solusi untuk mencapai satu kesepakatan atau beberapa kesepakatan yang mungkin saja menjadi jalan tengah bagi para kedua belah pihak. Kinerja mediator dituntut untuk bisa profesional, dari beberapa pihak yang dimediasi tidak semuanya bisa berkomunikasi dengan baik dalam menyampaikan permasalahannya. Mediator harus jeli dan dituntut untuk bisa mendalami setiap perkara yang ada. Mediasi di Pengadilan Agama Kabupaten Malang dilaksanakan dengan teliti, cermat dan hati-hati. Setiap mediator harus memastikan tahapan-tahapan tersampaikan dengan baik kepada para pihak. Hal ini untuk memberikan satu rangkaian acara mediasi sesuai dengan ketentuan yang ada dalam PERMA No. 1 tahun 2016 Tugas-tugas mediator dalam pelaksanaan tugas mediasi diharapkan mampu dimengerti dan dipahami oleh para pihak sehingga para pihak pun juga bisa lebih mengerti tentang tujuan dan fungsi serta apa mediasi itu sendiri. ${ }^{31}$

Mediator menfasilitasi para pihak dalam mediasi untuk menelusuri dan menggali kepentingan para pihak dari uraian serta penjelasan yang dilakukan oleh para pihak saat praktik mediasi berlangsung. Selain itu mediator juga melakukan beberapa pertimbangan dengan mencari berbagai pilihan penyelesaian yang terbaik bagi para pihak dan bekerjasama untuk mencapai sebuah perdamaian. Karena seringkali ditemukan para pihak yang terkesan bingung dalam menghadapi dan mencari penyelesaian atas perkara yang sedang dihadapi, disinilah peran mediator juga diperlukan untuk membantu para pihak dalam membuat dan merumuskan kesepakatan perdamaian. PERMA No.1 tahun 2016 memberikan ruang yang lebih luas untuk para mediator dalam melakukan perannya dalam tugas mediasi. Hal ini tentu sangat berpengaruh besar dalam hasil mediasi yang selama ini memang dinilai susah dalam mencapai tingat keberhasilan maupun menemukan kesepakatan bersama. ${ }^{32}$

Tingkat keberhasilan yang dicapai oleh setiap mediator sesuai dengan keterampilan dan pengetahuan asing-masing. Tingkat keberhasilan yang dicapai oleh setiap mediator akan menjadi satu kesatuan dalam sebuah ukuran keberhasilan yang dicapai oleh suatu pengadilan, karena itu setiap mediator yang bertugas dalam praktik mediasi dituntut untuk benar-benar bisa mencari celah serta menemukan beberapa opsi untuk kemudian bisa disepakati oleh para pihak, setiap mediasi yang berhasil mencapai kesepakatan perdamaian akan mendatangkan maslahah bagi kedua belah pihak. Banyaknya perkara yang diterima di Pengadilan Agama Kabupaten Malang menjadi satu tantangan tersendiri bagi setiap mediator. Pelayanan yang maksimal serta menangani perkara dengan keterampilan yang profesional menjadi salah satu faktor tercapainya keberhasilan dalam mediasi, Menurut Solihin indikator keberhasilan mediasi adalah pencabut perkara dan meminta putusan perdamaian. Hal tersebut tentu tidak mudah, namun bukan berarti tidak mungkin. Mediator dapat mengupayakan hasil yang baik dan maksimal dengan

\footnotetext{
${ }^{31}$ Solihin, Wawancara (Malang: 26 Oktober 2016)

32 Sudirman Hasan, Wawancara (Malang: 19 Oktober 2016)
} 
memberikan pelayanan mediasi yang baik juga professional, dengan begitu sangat dimungkinkan hasil dan tingkat keberhasilan mediasi bias dikatakan berhasil, atau lebih baik. $^{33}$

\section{Kesimpulan}

Berdasarkan pembahasan di atas dapat disimpulkan: Pertama, Mediasi merupakan bagian yang tidak dapat dipisahkan dari prosedur beracara di Pengadilan Agama sebagaimana diatur dalam Peraturan Mahkamah Agung RI Nomor 1 Tahun 2016 tentang Prosedur Mediasi di Pengadilan. Dalam Peraturan Mahkamah Agung RI Nomor 1 Tahun 2016 ditambahkan tentang ketentuan iktikad baik dalam pelaksanaan mediasi. Mediator memiliki wewenang untuk melakukan penilaian terhadap iktikad para pihak selama pelaksanaan mediasi. Bagi para pihak yang tidak memiliki iktikad baik dapat dikenai sanksi. Kewajiban beriktikad baik tidak hanya menjadi kewajiban para pihak, melainkan juga menjadi tanggung jawab kuasa hukum. Kedua, Pelaksanaan mediasi di Pengadilan Agama Kabupaten Malang sudah sesuai dengan ketentuan yang berlaku. Hasil mediasi di Pengadilan Agama Kabupaten Malang terbagi varian, yaitu mediasi berhasil, mediasi berhasil sebagian, dan mediasi gagal. Keberhasilan mediasi di Pengadilan Agama Kabupaten Malang erat kaitannya dengan iktikad baik para pihak. Meskipun demikian faktor pengetahuan terhadap mediasi dan keinginan pragmatis para pihak terhadap perkara yang diajukan di pengadilan menjadi faktor penghambat keberhasilan proses mediasi. Sedangkan faktor pendukung keberhasilan mediasi di Pengadilan Agama Kabupaten malang yaitu profesionalitas mediator yang menangani perkara dan fasilitas yang disediakan dalam ruang mediasi.

\section{Daftar Pustaka}

Antasari, Rina. "Pelaksanaan Mediasi dalam Sistem Peradilan Agama (Kajian Implementasi Mediasi dalam Penyelesaian Perkara di Pengadilan Agama Kelas I A Palembang).” Intizar 19, no. 1 (2013): 147-62.

Bintoro, Rahardi Wasi, and Tedi Sudrajat. "Analisis Mengenai Materi Muatan Peraturan Mahkamah Agung Nomor 2 Tahun 2003 Tentang Prosedur Mediasi Pengadilan.” Jurnal Dinamika Hukum 8, no. 1 (January 15, 2008): 1-12. https://doi.org/10.20884/1.jdh.2008.8.1.16.

Fanani, Ahwan. Pengantar Mediasi (Fasilitatif), Prinsip, Metode, Dan Teknik. Semarang: Fakultas Tarbiyah IAIN Walisongo Semarang, 2012.

Hairi, Prianter Jaya. "Antara Prinsip Sederhana, Cepat, Dan Berbiaya Ringan Dan Gagasan Pembatasan Perkara Kasasi." Negara Hukum 2, no. 1 (June 2011).

Innaka, Antari, Saida Rusdiana, and Sularto. "Penerapan Asas Iktikad Baik Terhadap Pra Kontraktual Pada Perjanjian Jual Beli Perumahan." Mimbar Hukum 24, no. 3 (2012).

Mantili, Rai, and Samanta Aulia Lubis. "Pertimbangan Hakim Pengadilan Negeri Terhadap Gugatan Perceraian Yang Tidak Dapat Diterima (Niet Ontvankelijke Verklaard) Dalam Praktik." ADHAPER: Jurnal Hukum Acara Perdata 3, no. 1 (2017).

Marwah. "Asas Iktikad Baik Dalam Perjanjian Kredit Pemilikan Rumah.” Jurisprudentie 3, no. 1 (2016).

\footnotetext{
${ }^{33}$ Solihin, Wawancara (Malang: 26 Oktober 2016)
} 
Musawwamah, Siti. "Mediasi Integratif Di Pengadilan Agama Pamekasan." NUANSA: Jurnal Penelitian Ilmu Sosial Dan Keagamaan Islam 11, no. 2 (January 18, 2014). https://doi.org/10.19105/nuansa.v11i2.537.

Mustika, Dian. "Efektivitas Mediasi Dalam Penyelesaian Perkara Perceraian Di Pengadilan Agama Jambi." AL-RISALAH 15, no. 2 (December 20, 2015): 297308.

Pengadilan Agama Kabupaten Malang. "Laporan Statistik Perkara Pengadilan Agama Kabupaten Malang 2016," October 2016. https://sipp.pamalangkab.go.id/statistik_perkara.

Peraturan Mahkamah Agung Nomor 1 tahun 2016 tentang Prosedur Mediasi di Pengadilan

Purba, Iman Pasu Marganda Hadirto. "Penguatan Budaya Hukum Masyarakat Untuk Menghasilkan Kewarganegaraan Transformatif." Jurnal Civics 14, no. 2 (October 2017).

Raharjo, Agus. "Mediasi Sebagai Basis Dalam Penyelesaian Perkara Pidana." Mimbar Hukum - Fakultas Hukum Universitas Gadjah Mada 20, no. 1 (2008). https://doi.org/10.22146/jmh.16316.

Rahmawati, Erik Sabti. "Implikasi Mediasi Bagi Para Pihak yang Berperkara di Pengadilan Agama Malang." De Jure: Jurnal Hukum dan Syariah 8, no. 1 (June 25, 2016): 1-14. https://doi.org/10.18860/j-fsh.v8i1.3725.

Siradjuddin, Siradjuddin. "Akar-Akar Konflik Fundamental Perspektif Ekonomi Politik." Jurnal Iqtisaduna 1, no. 2 (December 19, 2015): 17-39. https://doi.org/10.24252/iqtisaduna.v1i2.1192.

Supardi, Supardi, and Zahrotul Hanifiyah. "Penyebab Kegagalan Mediasi Dalam Proses Perceraian (Studi Kasus Di Pengadilan Agama Kudus Periode Januari-April 2017)." YUDISIA : Jurnal Pemikiran Hukum Dan Hukum Islam 8, no. 1 (April 8, 2018): 155-77. https://doi.org/10.21043/yudisia.v8i1.3224.

Sutiyoso, Bambang. Hukum Arbitrase Dan Alternatif Penyelesaian Sengketa. Yogyakarta: Gama Media, 2008.

Suyahmo. "Model Implementasi Sila Ke 4 Kerakyatan Yang Dipimpin Oleh Hikmat Kebijaksanaan Dalam Permusyawaratan/Perwakilan Sebagai Lokus Pendidikan Demokrasi Di Smp Kota Semarang." Jurnal Penelitian Pendidikan 32, no. 1 (2015).

Talli, Abdul Halim. "Mediasi dalam PERMA Nomor 1 Tahun 2008." Jurnal Al-Qadau: Peradilan dan Hukum Keluarga Islam 2, no. 1 (June 8, 2015): 76-93.

Undang-Undang Nomor 3 Tahun 2006 tentang Perubahan Atas Undang-Undang Nomor 7 Tahun 1989 tentang Peradilan Agama

Undang-Undang Nomor 50 tahun 2009 tentang Perubahan Kedua Atas Undang-Undang Nomor 7 Tahun 1989 tentang Peradilan Agama 